\title{
The Power of Corruption: Xenophon on the Upbringing of a Good Citizen in Sparta*
}

\author{
Aleksandr Mishurin \\ $\mathrm{PhD}$ in Political Science, Associate Professor, Faculty of Political Science, \\ State Academic University for the Humanities \\ Address: Maronovskiy pereulok, 26, Moscow, Russian Federation 119049 \\ E-mail: amishurin@gaugn.ru
}

\begin{abstract}
In the given article, the author offers an interpretation of the work titled Lacedaimonion Politeia, written by the ancient political philosopher Xenophon of Athens. Judging from Xenophon's sober and open-minded attitude to the regime he researches, the author focuses on the central issue of the treatise, namely, the upbringing of a virtuous or good citizen. This became the cornerstone of Sparta's success as a polis, and provided it with a fame as a unique political entity praised by all, but copied by none. The author identifies the three stages of the Spartan education given by Xenophon and continues with the practices of its implementation at a mature age. The research makes it clear that the purpose of the laws of Lycurgus, as described by Xenophon, is twofold. On the one hand, the given laws instill respect, obedience, and the virtue of manliness which the lawgiver desired in citizens. On the other hand, the laws create citizens who merely imitate the above-described traits of character and lawabidance, and who are actually more like unmitigated criminals constantly fighting with each other. It is the second type of people-good criminals-who find themselves in power in Sparta, and they are the ones who end up destroying the Spartan state. By providing this diagnosis of the Spartan regime and the laws of Lycurgus, Xenophon attempts to show that handling the problem of the education of good citizens as suggested in Sparta is misguided and requires additional deliberation.
\end{abstract}

Keywords: Xenophon, Sparta, virtue, imitation, upbringing, education

Sparta was and remains one of the most remarkable political phenomena in history. However, due to the closed nature of the polis, ${ }^{1}$ even its contemporaries knew little about the Spartan regime and its way of life. Rather, like us, they had only a general notion of it, for the creation and spreading of which the Spartiates themselves took little or no credit. Nowadays, this conception is traditionally referred to as "the Spartan mirage" (Rahe, 2016: 2). Various features of "the Spartan mirage" have been highlighted over the years since the Renaissance, depending on the political tasks they were meant to solve.

N. Machiavelli viewed Sparta as a model of a perfect and stable republic (2007: 24), armed and free (2008: 223). J.-J. Rousseau was impressed by the simple and noble way of

\footnotetext{
* Статья подготовлена при финансовой поддержке в рамках выполнения государственного задания ГАУГН по теме «Современное информационное общество и цифровая наука: когнитивные, экономические, политические и правовые аспекты» (FZNF-2020-о014).

I must express my gratitude to Prof. Alexander Filippov for his valuable remarks and guidance.

1. I will treat the terms "polis" and "state" as interchangeable.
} 
life of Spartan society, including the patriotism, manliness, and solidarity prevailing in it (Shklar, 1966; Oprea, 2019; Mason, 2018: 670-675). The Enlightenment thinkers and French revolutionaries considered Sparta to be a prototype of the proper approach to mass education (Mehta, 2016; Morris, 2004). For German thinkers since the XVIII century, Sparta has been either the embodiment of orderliness, discipline, and militarism (Roche, 2012a; Rebenich, 2018: 688-692) or a model of elitism (Rebenich, 2018: 692696), or even the forerunner of totalitarianism (Rebenich, 2018: 696-700; Roche, 2012b).

The classical political philosophers were far more critical of Sparta. In the Republic, Plato states that the Spartan regime represents a stage of the decay of the ideal state, the "intermediate between aristocracy and oligarchy" (1942: 547c7-8), doomed to degenerate into oligarchy as a result of the private enrichment of its citizens (550d2-e10). The criticism in the Laws focuses mainly on the idea that Spartan laws are established only with war in mind and that the polis cultivates only the lowest virtue, namely, manliness, in its citizens (1926: 63ob9-d7). Aristotle confirms this view in the Politics (1932: 1271a41-b3), though he criticizes far more aspects of the Spartan regime (Lockwood, 2017). Aristotle lists issues with helots, Spartan women, and property (and the scarcity of people as its consequence), as well as issues with the power of ephors, members of the Council of Elders, and navarchs, and problems with shared meals and state finances (1932: 1269a291271b19).

On the other hand, both Plato and Aristotle highly appreciate the Spartan regime as they both describe Sparta as the state that claims to be the closest to the best regime. In this context, the study of the polis or its parts (Powell, 2015: 92) contributes to the study of the issue of the best regime. Formulated differently, although Ancient Greek philosophers were critical of the state-military camp (Plato, 1926: 666d9-667a5; Aristotle, 1932: 1271a41-b3), ${ }^{2}$ they employed their knowledge of Sparta to handle more essential concerns. Perhaps the main one among them is the question of virtue (ả $\rho \varepsilon \tau \dot{\eta})$. The best regime is not the most stable or the richest or the most free but, rather, the regime that can make its citizens into the best men; it is the regime that can make its citizens virtuous. All the characteristics of a good regime that seem to be key today are based particularly on the virtuousness of the citizens. Therefore, the political, a regime, deserves serious attention if it can instill at least one virtue, even the lowest one, into the citizens. ${ }^{3}$

Unlike Plato and Aristotle, Xenophon of Athens did not write a work dedicated to the problem of the best regime. However, as fate would have it, he was as close to Sparta as was possible for a non-Spartan. Xenophon described the Spartan regime in his treatise titled Lacedaimonion Politeia. ${ }^{4}$ While there has been a surge of interest in his heritage since the second third of the twentieth century, Xenophon remains a problematic figure in the

2. This idea has been questioned recently, though no major achievements have been made (see Hodkinson, 2006: 111-162).

3. For example, Plato did not believe that it could be done. In The Republic, Plato states that most of the citizens cannot be made truly virtuous; they can only have some substitutes for virtues (Lutz, 1997).

4. It partially made Xenophon one of the creators of "the Spartan mirage", along with Plutarch, Isocrates, and others. 
history of philosophy, and his works continue to stir up a seemingly endless dispute. ${ }^{5}$ The discussion surrounding the Lacedaimonion Politeia is interesting and ample proof of the given dispute, which distinguishes three main positions towards Xenophon and his work. The first position is that Xenophon was a simple and consistent laconophile, and the Lacedaimonion Politeia is an unscrupulous encomium to Sparta (Cartledge, 1999: 318-321; Gray, 2007: 231). The second position is that Xenophon was a laconophile at some point in his life but changed his mindset, and this change could be clearly seen in the Lacedaimonion Politeia (Tigerstedt, 1965: 159-179; Dillery, 2017: 199-201; Powell, 2018: $5,8)$. The third position is that Xenophon was not a laconophile, and his "encomium" is an example of applying the Socratic irony to the Spartan regime (Strauss 1939). ${ }^{6}$ It is a rarity among the most notable and active researchers of Xenophon's legacy to hold the idea that the Lacedaimonion Politeia is a philosophical treatise and that its author can take an unbiased look at, analyze, and describe both the advantages and disadvantages of the regime under investigation (Humble, 1997, 2004, 2012, 2018a). However, one should accept the above-mentioned point of view if one intends to carefully approach the study of Xenophon's philosophy in general, and his work Lacedaimonion Politeia in particular.

Aside from the problematic character of the author's and the treatise's (pro-Spartan or anti-Spartan) orientation, the Lacedaimonion Politeia has a set of features that presents difficulties for modern scholars. It is still not clear as to when the work was written. ${ }^{7}$ The relationship between the Lacedaimonion Politeia and the works of Plato and Isocrates is a problem (Humble, 2018a, 2018b). No less opaque are the relations of the treaty with the common Greek views on Sparta. ${ }^{8}$ The role of the clearly noticeable citations and self-citations in the Lacedaimonion Politeia remains nebulous, as well as the relationship between images of Sparta and Persia, described in the Lacedaimonion Politeia and the Cyropaedia (Tuplin, 1994: 127-181). ${ }^{9}$ The problems arise with respect to the treatise's title, which seemingly fails to reflect the content of the treatise (Strauss, 1939: 502; Proietti, 1987: 47). ${ }^{10}$ The work formally devoted to the description of the Spartan political system scarcely describes its functioning, its composition, and the structure of its political

5. Even in the late 2oth century, researchers had to dispel myths about Xenophon being a poor historian and narrow-minded thinker (see Proietti, 1987). Major scholars of Xenophon's heritage often did not want to identify him as a philosopher. For example, Eugene Tigerstedt puts Xenophon in the historical section of his monumental work on Sparta and refuses to mention Xenophon in the philosophical section (1965).

6. It should be noted separately that there is a fourth position that is not raised nowadays, but could still be feasible - namely, that Xenophon might not be the author of the Lacedaimonion Politeia (see Chrimes, 1948; Talbert, 2005).

7. The critical nature of Chapter XIV of the treatise supports the popular view that the Lacedaimonion Politeia was written after the Spartan defeat in the battle of Leuctra but before the battle of Mantinea (Dillery, 2017: 200). However, there is no external evidence of this view (see Lane, 2016: 124).

8. Especially considering the almost polemic nature of the treatise reflected by the systematic contrast of Sparta and the rest of the Greek poleis (Ducat, 2006: 6).

9. According to Christopher Tuplin, Xenophon does not try to show the readers Sparta, depicting it as Persia in the Cyropaedia. In this regard, Tuplin compares various aspects of Sparta and Persia, such as royalty, the concept of "equals", shared meals, education, etc. However, he disregards the possibility that Persia, as described by Xenophon, could be his idealized version of Sparta.

10. Leo Strauss believes that the titles of Xenophon's works purposely confuse the readers (1975: 117). 
institutions (Proietti, 1987: 46-47; Tigerstedt, 1965: 163). ${ }^{11}$ Xenophon even conceals the existence of some political institutions and does so not out of ignorance. ${ }^{12}$ Particular attention should be paid to the puzzling structure of the work which contains a chapter clearly dispelling its original thesis. Chapter XIV of the Lacedaimonion Politeia is often criticized, as it is said to be written after the main bulk of the treatise, or even not issued from Xenophon's pen at all (see Proietti, 1987: 45-46; Strauss, 1939: 521-525; Tigerstedt, 1965: 168-169; Lipka, 2002: 27-31). ${ }^{13}$

All of the aforementioned aspects complicate the understanding of the Lacedaimonion Politeia as an integral work, especially considering its small size. However, the treatise content indicates that the key topic of the treatise is the upbringing of a good or virtuous citizen. ${ }^{14}$ Most of the treatise is devoted to the description of peaceful life (Chapters I-X and XV), while only the fifth part (Chapters XI-XIII) depicts war (both preparations for war and waging war). Chapter XIV delves into the results-or, rather, the failure-of Spartan education, which (and not the defeat in military actions) led to the decay of the Spartan regime. Though the military education went hand in hand with the civil education and could hardly be separated from it, just as the social roles of a citizen and a soldier are intertwined, it is perfectly clear exactly what Xenophon emphasized in the treatise.

Finally, it should not go unmentioned that the article does not focus on revealing any historically accurate or verified facts about the Spartan regime. Trying to see the "real" Sparta in the Sparta described in the Lacedaimonion Politeia would be tantamount to trying to see the "real" historical Socrates in the Symposium or the Apology (cf. Ducat, 2006: 21-22). The article addresses Xenophon's philosophy, thoughts, and views contained in this and, partly, in some of his other works.

\section{Childhood, Adolescence, Youth}

All over Greece, literacy, music, and gymnastics are the first steps in the education of a future citizen (Xenophon, 1968: II, 1). However, the Spartan system of education immediately stands out from the rest. ${ }^{15}$ First, Spartan children are educated centrally by

11. Xenophon describes only the formation and function of the Council of Elders, and partially notes the functions of the ephors and royal power, leaving unmentioned that, officially, Sparta is governed by two kings (see Strauss, 1939: 526).

12. For example, the existence of the Little Assembly in Sparta is known from the Hellenica only (Xenophon, 1961: III, 3, 8).

13. Though there is a similar chapter in the Cyropaedia that also disproves the content of the work (Xenophon, 1914: VIII, 8).

14. The use of the term 'citizen' is a tribute to the time and not an attempt to match and reflect the term

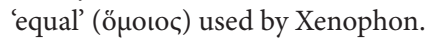

15. All but one fundamental statement of the treatise are formulated by contrasting Sparta with other Greek states. The upbringing and lifestyle of free women are contrasted in I, 3-4; marriage and childbearing are contrasted in I, 5-10; upbringing and education of boys are contrasted in II, 1-5; the practice of pederasty is contrasted in II, 12-15; the education of adolescents is contrasted in III, 1-3; the physical activity of mature men is contrasted in IV, 7 ; dining practice is contrasted in V, 2; the physical development of adults is contrasted in V, 8-9; the attitude towards children and property is contrasted in VI, 1-5; the professions and wealth ac- 
the state; Spartan education is not private. Second, the state itself decides what subjects to teach and what training methods to use to make virtuous or good citizens out of Spartan boys (II, 2-8). Spartan education includes the following subjects: physical endurance, stealing, and submission. ${ }^{16}$ Xenophon dwells on all subjects in detail. To develop physical endurance, the boys are forced to walk barefoot, wear one type of clothing all year round, and get an insufficient amount of food and sleep (II, 3-5 and 7). ${ }^{17}$ To teach the boys to submit (in other words, to respect the authorities and obey the superior's orders), ${ }^{18}$ the boys are constantly surveilled, either by their direct supervisor-the war-

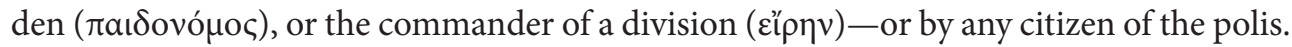
Only fear of punishment motivates the boys to obey orders and respect their superiors (Xenophon, 1968: II, 2, 10-11 and VI, 2; Powell, 2018: 37; Rahe, 2016: 12; Humble, 2018a: 564-565). As a result, a future citizen lives under surveillance from an early age. The surveillance goes hand in hand with the fear of immediate punishment. Spartan education seems to concentrate only on punishment (Humble, 2018a: 563-564; Christensen, 2016: 387; Hodkinson, 2005: 248). To teach the boys to steal, they are not given enough food, and to teach the boys to steal well, those who get caught stealing are severely punished (Xenophon, 1968: II, 2, 5-9). ${ }^{19}$ Formulated differently, the polis trains its future citizens to violate the laws effectively, which requires the following: the impetus for the violation (hunger), the minimization of the possibility of it (surveillance), and the immediate severe punishment of unsuccessful criminals.

cumulation of citizens are contrasted in VII, 1-2; the best citizens' attitude towards the authorities is contrasted in VIII, 1-2; the power of the highest authority is contrasted in VIII, 4; the treatment of cowards is contrasted in IX, 4-6; the attitude towards virtue is contrasted in X, 4; the treatment of non-virtuous citizens is contrasted in X, 5-6. Finally, in X, 8, Xenophon concludes that the Spartan practices are uncommon for other states that praise them, and yet no state wants to copy them. However, despite this conclusion, Xenophon continues to contrast. First, one could say that all "military" chapters aim to show that "Lycurgus' organization of the army on active service was better than other systems" (1968: XI, 1). Secondly, Xenophon opposes the stability of the Spartan regime to the instability of other regimes $(\mathrm{XV}, 1)$.

16. Xenophon leaves literacy, music, and gymnastics in the Spartiates' training unmentioned. There are two opposite explanations of this feature of his work. Strauss (1939: 507) believes that, by doing so, Xenophon exposes the absolute indifference of the state to the cultivation of corresponding skills in boys. Michael Lipka (2002: 116) states that the assumption fails to agree with the external data and modern views on Sparta: "Undoubtedly, music was essential to the Spartan education and the majority of the Spartiates were partly literate". Yet these two explanations can be combined without major problems; though the state did not teach the Spartiates these subjects, this does not mean that the Spartiates could not receive basic education elsewhere, for example, at home or during military expeditions (Xenophon, 1968: XII, 5-6; Ducat, 2006: 119-135 and 333-334: Hansen and Hodkinson, 2009: 485-488).

17. A noteworthy detail is that the goal list of physical training of Spartan boys is almost identical to

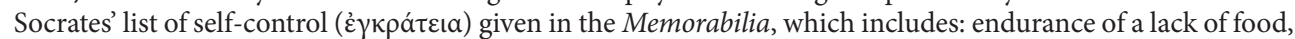
wine, sex, and sleep, and endurance of hard labor, heat, and cold (2013a: I, 2, 1 and 5, 1; II, 1, 1). According to Xenophon, the Spartan citizens cannot control themselves when it comes to wine consumption, which will be developed further below.

18. Xenophon uses the special terms $\pi \varepsilon i \theta \omega$ (obedience) and ai $\delta \omega ́ \varsigma$ (shame/respect) to denote the discussed traits. Lipka investigates their meaning in Xenophon's works (2002: 119-120).

19. Almost all authors, starting with Strauss, believe that the polis purposely teaches the Spartiates to steal (Strauss, 1939: 507-509; Proietti, 1987: 49; Humble, 2018b: 68; Ducat, 2006: 6; Rahe, 2016: 13; Tuplin, 1994: 156-157). However, some exceptions can be found. For example, Paul Christensen thinks that teaching to steal is an accidental side-effect of the Spartan education system (2016: 389). 
How does the teaching to submit couple with the teaching to violate laws effectively? It seems that the lawgiver Lycurgus' thought was to train future citizens to display their absolute loyalty to the authorities publicly from an early age. ${ }^{20}$ The lawgiver believed that one could not instill full orderliness in citizens. However, he considered the public imitation of orderliness to be achievable. The punishment for any fault noticed by a superior would train the boys to be in awe of their superiors (ai $\delta \omega \varsigma$ ), and, thus, to obey all their orders $\left(\pi \varepsilon^{\prime} \theta \omega\right)$. However, this means that as soon as the boys manage to escape surveillance or as soon as their supervisors are not there, the necessity of following the laws of the polis immediately falls away, as this is closely connected to punishment which in itself is contingent on the success of the surveillance. The motivation to follow the laws and behave correspondingly is always external. ${ }^{21}$ Still, to give a boy an opportunity to violate the law and to force him to do so through teaching are two different matters. To understand the educational goal of the effective violation of laws, one should analyze the whole education process as well as its results.

When boys enter adolescence, ${ }^{22}$ their "self-will makes strong root in mind, a tendency to insolence manifests itself, and a keen appetite for pleasure in different forms takes possession" (III, 2). ${ }^{23}$ To stifle their vicious desires, the polis imposes some unnamed works on adolescents (Ibid.). In doing so, both the authorities and, most notably, the relatives of the adolescents are charged with monitoring the adolescents to ensure that they perform that work. The surveillance is escalated (unlike boys, adolescents cannot find relief even at home, and thereby lose a great part of their privacy). Along with this, the punishment is more severe. An adolescent found skulking around loses some unnamed political benefits. ${ }^{24}$ Obviously, adolescents do not need to be forced to steal food. They have already completed this stage of their education, and can now eat with the elders (III, 5; V, 5). At this educational stage, adolescents are taught to dodge the responsibilities that the state imposes on them. The stimulus increases alongside the task complexity (escalation of the surveillance and punishment) and the benefits reaped from effective law violation. According to Xenophon, Lycurgus was quite aware that a natural desire increases when it is limited or stifled $(I, 5)$. That is why limiting the adolescents' natural pursuit of pleasure, insolence, and self-will only excites them, and provokes the strongest and most capable of them to violate the laws successfully.

Adolescents are still trained to be in awe of their superiors. They must keep their hands under their clothes, keep silent until the elders speak to them, and not look up (III, 4-5). This somewhat trivial remark is accompanied by a commentary on the first

20. Some scholars believe that it refers to the obedience of the authorities and not the laws (Proietti, 1987: 59; Lane, 2016: 125).

21. According to Xenophon, the Spartiates are immoderate. See note 25 (cf. Hodkinson, 2005: 248; Humble, 1997: 197-198 and 204-205).

22. Tuplin presents the table illustrating the stages of Spartan education and the corresponding age for each stage (1994: 153).

23. All the citations are taken from the 1968 edition of the text translated by E. C. Marchant.

24. Xenophon's Anabasis describes Dracontius the Spartiate, who, as an adolescent, killed another boy by accident and was exiled (1998: IV, 8, 25). 


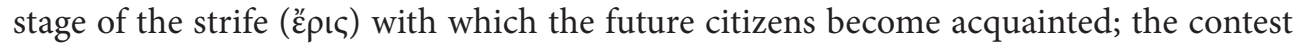
between the sexes (cf. Strauss, 1939: 505-506). Adolescents who have never been taught to be moderate (even the above-mentioned requirements for their behavior are classified

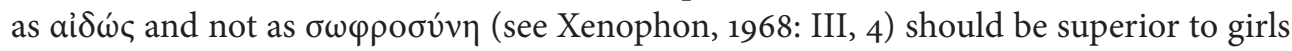
in terms of moderation and respectful behavior. ${ }^{25}$

The strife is only aggravated when the adolescents become young males. Now, the state seeks to instill in them "the spirit of rivalry" ( $\varphi$ ı ovıкía) (IV, 2). ${ }^{26}$ With this view, the ephors choose the three best young males; then, each of them recruits a body of troops of one hundred peers, "stating his reasons for preferring one and rejecting another" (IV, 3). After that, strife breaks out between the groups of the chosen and ignored young males, and sometimes takes the form of open enmity. The young males try to publicly prove their superiority, watch each other constantly, and wait until their rival makes a slip which is then immediately denounced to the authorities and punished (IV, 4-5). It seems that this, together with the strife that escalates into hostility and open conflicts between young males, is part of the education process. Any citizen can break them up, and if some young males refuse to obey, they can be brought to the ephors for punishment $(\mathrm{IV}, 6)$. It is, however, only partly true (Ibid.).

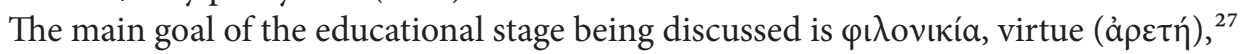

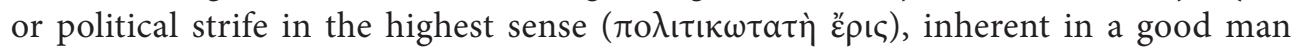

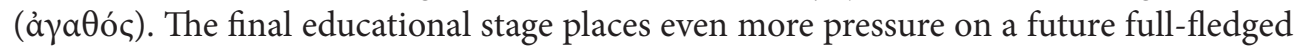
Spartiate. Now, not only are the authorities, the citizens, and his relatives surveilling him, but so, too, are his peers. A previously homogeneous group of peers breaks up. The punishment becomes even more severe than before. Though Xenophon does not mention this explicitly, it is clear that a young male who fails to undergo this educational stage labels himself as a coward (surely, the educational goal is to display and imitate manliness). Later, Xenophon clearly illustrates that Sparta is no place for cowards (IX, 3-6; X, 5-7). The fact that the people punishing the young males are those who have the highest authority, i.e., the ephors, and not the citizens or lower ranks (who punished a delinquent in the previous stages) indicates the gravity of the punishment. ${ }^{28}$ Seemingly, all the discussed schemes are aimed at providing instruction in the successful violation of

25. This is the only reference to moderation in the entire work (except for XIII, 5 , where the meaning of the term "moderation" is quite limited). While only one feature of moderation, taciturnity, is mentioned in the context, it hardly allows for the comparison of this "moderation" to the philosophical moderation of Socrates as seen in the Memorabilia. Socrates is moderate, but he cannot be called taciturn. One could say that it is another criticism of Spartan women; the boys who have never been trained to be moderate are still much more moderate than the Spartan girls.

26. Mentioning this, Xenophon points out, for the first and only time, that Lycurgus borrowed the idea and principles of the practice from other Greeks. This remark demands attention, since the bulk of the treatise is formulated through the contrast between Sparta and other Greek states. See note 15.

27. All commentators agree that, here, virtue is understood solely as manliness (Strauss, 1939: 520-521; Lipka, 2002: 143). The list of Socrates' virtues from the Memorabilia does not include manliness (Xenophon, 2013a: IV, 8, 11). See note 30.

28. Though Xenophon never openly claims that the ephors have the ultimate state power, his description of the Spartan state institutions does not allow for any another conclusion (Strauss, 1939: 526). Apparently, other third-party sources verify this (see Hodkinson, 2005: 239). 
laws. This is clearly aligned with the declared educational goal at this stage. Alongside the already-known purely formal submission to the authorities and the laws, stemming from the fear of getting caught and being punished, future full-fledged citizens are taught to be manly. However, a closer look reveals that this is wrong. The public demonstration of manliness, and not the upbringing of manly people, is discussed from the very beginning. This is shown by the already uncovered features of the Spartan education, some passages from Chapter IV, and the following chapters.

The chapter opens $(I V, 2)$ with a statement that attracts attention as it differs in style from the previous and following passages in the text. ${ }^{29}$ Lycurgus saw "that where the spirit of rivalry ( $\varphi \iota \lambda$ ovıкia) is strongest among the people, there the choruses are most worth hearing and the athletic contests afford the finest spectacle. He believed, therefore, that if he could match the young men together in a strife of valor, they too would reach a high level of manly excellence" ${ }^{30}$ (emphasis added). Thus, the lawgiver's aim was not to instill manliness in the citizens' hearts, but to force them to imitate virtue and to do so publicly. The groups of young males should fight with each other whenever they meet to show their manliness, but their "manliness" should never outshine their submission to the superiors (IV, 6). In adult life, the imitation of manliness is supported by numerous punishments for cowards, punishments that are harder to bear than a "brave" death (IX, 3 and 6). There are the following punishments for cowards: exclusion from shared meals, gymnastic competitions, and collective games; the humiliation of a change in status in society (the "ignominious" places in choirs, the demand to make way for juniors, the prohibition to act normal); and the preclusion of getting married and giving daughters to marriage (IX, 4-5). The final stage of social exclusion is the loss of citizenship (X, 7).

Naturally, military battle is the key element of the imitation of manliness. Xenophon gives due consideration to this question. Since imitation is closely associated with sight and hearing, it could be called 'image' nowadays. The lawgiver did a great deal to ensure that the Spartiates cultivated the image of manly warriors. First, a manly warrior apparently has a strong body. To shape such a body, Lycurgus issued several eugenic laws (I, 4-8), ${ }^{31}$ cut the food allowance of adults and children to prevent them from gaining weight (II, $5 ; \mathrm{V}, 8$ ), and introduced physical activity for children and young males (stealing and fighting) (II, 6-7; IV, 6), as well as for adults (hunting and dancing) (IV, 7; V, $9)^{32}$ and soldiers in the field (gymnastics) (XII, 5). Secondly, a manly warrior must look terrifying. That is why the lawgiver provided the Spartiates with red cloaks ("because he

29. I have already stated why this statement stands out from the text. See notes 15 and 26.

30. In the Lacedaimonion Politeia, Xenophon never uses the word "manliness" (åv $\delta \rho \varepsilon i ́ a)$ and always uses

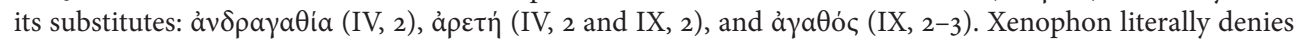
manliness to the Spartiates.

31. However, Xenophon does not state that the practice leads to the desired effect (I, 10; cf. II, 15).

32. Certainly, Xenophon would not mention dancing openly (he does not mention the choirs openly; choir practice of the Spartiates is mentioned in Xenophon's description of the cowards' exclusion from the "good" places in the choirs (IX, 5)). Xenophon mentions that Lycurgus managed to make the Spartiates healthy and strong in the body $(\mathrm{V}, 9)$ as they "train the legs, arms and neck equally". Xenophon only once uses this formula in the Symposium, when Socrates jokes that dancing is the best gymnastics, as "no part of (a) body was idle during the dance, but neck, legs, and hands were all active together" (2013b: 2, 16); and Xenophon himself 
believed this garment to have the least resemblance to women's clothing and to be most suitable for war") (emphasis added) and brass and not bronze shields ("because it is very soon polished and tarnishes very slowly"-in other words, it looks shiny longer) and let their hair grow as barbarians do ("believing that it would make them look taller, more dignified, and more terrifying") (emphasis added) (XI, 3; cf. XII, 5). They marched into battle with wreaths on their heads, polished weapons, and oiled hair ("to look cheerful and earn a good report") (emphasis added) (XIII, 8-9). The lawgiver invented another way to imitate manliness for aged Spartiates who cannot be warriors any longer, and thus cannot demonstrate their manliness in sparring (as the young males do) or in battles (as the adults do). The aged men still evince their manliness publicly through the war of words for an elective position in the Council of Elders $(\mathrm{X}, 3) .{ }^{33}$ Once again, punishment motivates them to engage in strife. However, now the men are motivated not by the threat of punishment due to non-participation or defeat but, rather, by the power to punish as a result of winning the strife: Xenophon describes the only function of the Council of Elders being the capital punishment court (Xenophon, 1968: X, 2; VIII, 4; Humble, 2018a: 567).

The question of the imitation of the virtue of manliness seems to be the core question of imitation in general, that is, of imitation as a consequence of Spartan education. The statements on manliness given in three different chapters prove this. In Chapter IX, Xenophon states that citizens' manliness glorifies and strengthens their fatherland; "glory adheres to the side of valor, for all men want to ally themselves somehow with the brave" (1968: IX, 2). The statement is referred to again, and somewhat supplemented, in Chapter X: if the state's power and glory depend on the manliness of its citizens, then cowards, by virtue of their very existence, commit the supreme crime against the state $(X, 4$ and 6). Crucially, Chapter XIV, in which Xenophon accuses the Spartiates of the dereliction of the laws of Lycurgus, states that if the Greeks previously wanted to be allied with the Spartiates (when they obeyed the laws of Lycurgus), they now want to join their forces against the Spartiates (XIV, 6). The combination of these three statements creates the following picture. Lycurgus thought that the citizens' demonstration of only one virtue, namely, manliness, could make Sparta a strong polis. However, Lycurgus reached "the utmost limit of wisdom" (I, 2) and understood that people could not be made manly. The mere understanding of this fact does not show his wisdom which lies in his identifying the solution to the issue. Instead of trying to achieve the impossible and to instill the virtue of manliness in his citizens, he decided to force them to imitate the virtue. Apparently, this approach worked up to a point. To understand what ruined Sparta and the legislation of Lycurgus, one should move from education to the implementation of its results.

confirms this later $(2,22)$. This explains why the chapter about binges concludes with a statement about strong and healthy people, as alcohol, group activities, and dancing are interrelated.

33. It is worth drawing attention to the fact that Xenophon mentions in the passage again that this demonstration has something in common with choral and gymnastic contests that should be enjoyable for the audience (cf. 1968: IV, 2). 


\section{Maturity}

In adult life, the Spartiates must obviously maintain the gained-through-training skills of the public imitation of respect, obedience, and manliness. The lawgiver invented several unique mechanisms in this regard. The most important among them, as Xenophon shows, is limiting privacy; that is, limiting the situations in which a male Spartiate could get away from the eyes of other male Spartiates and escape from surveillance and public strife (Ducat, 2006: 17). Xenophon starts a discussion of the topic with the most fundamental thing, food. Adult Spartiates are precluded from eating at home, as this activity is "responsible for a great deal of misconduct" (1968: V, 2). ${ }^{34}$ However, a Spartiate is still permitted by law to stay out of sight after meals. Citizens, as drunk as drunk can be, walk home without torchlight; no one should see a Spartiate drunk, crawling on his hands and knees. At the same time, no one should find a Spartiate sleeping by the side of the road the following morning $(\mathrm{V}, 7) \cdot{ }^{35}$ The lawgiver's idea seems simple: one can hardly ban alcohol, but one can prohibit the citizens from showing the unpleasant consequences of alcohol consumption.

The next matter at hand in terms of limiting privacy is property, including children. To instill obedience and respect, any elder is known to command juniors and punish them for any offense (VI, 2). However, the context of the chapter points to another side of this practice, namely, the preclusion of fathers from their overwhelming right to control and punish their children. The Spartiate's family hearth is ruined partly by this, partly by adultery (referred to below), and partly by strife, as neither his children or his wife, nor his relatives can be close to him and belong to his private circle. As to property, the ideas of Lycurgus are also consistent. On the one hand, an adult citizen can always seize someone else's property. If the property seized can resist the seizing, the Spartiate must obtain the consent of its owner to do so; if not, consent is not needed (VI, 3-4). On the other hand, the description of seizing property without the owner's consent given by Xenophon de facto depicts a successful criminal act. Two versions are provided. If the 'usurper' takes something too valuable, which can be easily discovered or whose possession cannot be concealed, that is, if he fears getting caught, he can return everything stolen unnoticed after having used it. The property remains with the thief if the 'taken' can be easily hidden or used without a trace, as no-one can be charged with the seizing. The reason for such permission from the state lies not only in maintaining and cultivating skills gained through training, but also in the provision of the climate of strife and limiting citizens' privacy. If they let down their guard, the Spartiates may irreparably lose their property.

34. The rule applies even to the Spartan kings (1968: XV, 4-5), presumably for the same purpose.

35. There are two opposing viewpoints on the mentioned drinking custom. According to Strauss, Lycurgus supported drunkenness, allowing drinking alcohol like water "to quench the thirst" (1939: 515). Describing various discrepancies, Lipka assumes that the laws prohibit the Spartiates from getting drunk (2002: 153-154). In doing so, Lipka cites an obviously mocking remark (Xenophon, 2013b: 1, 1) made by Xenophon's Socrates in the Symposium (2013b: 2, 25). However, the context of the chapter (doddering drunk Spartiates) and its message rather refers to Plato's Symposium, which describes drinking "to quench the thirst" as a nonsensical binge (1925: 214a8-b2). 
None of the property belongs to them in the full sense of the word. An unexposed crime counts for nothing in the state that brings up criminals. This is what Xenophon underlines by saying that Lycurgus believed that "enslavement, fraud, robbery, are crimes that injure only the victims of them; but the wicked man and the coward are traitors to the whole body politic" (X, 6). Formulated differently, the lawgiver was quite aware that the existence of the state ranks above the well-being of its citizens. Hence, the latter may be (and apparently should be) sacrificed for the benefit of the former.

Concerning wealth accumulation, Xenophon keeps describing a familiar image. Income inequality (Xenophon, 1968: I, 9 and VI, 5; Hodkinson, 1994: 192-193) in a society in which privacy is absent or almost absent, and that instigates its citizens to contest by the state seems to inevitably result in conspicuous consumption (Xenophon, 1968: XIV, 3). The laws race to the rescue. Firstly, an honest and open way to enrich is prohibited; a Spartiate cannot pursue any profession except the trade of war (VII, 1-2). Secondly, it is impossible to enrich honestly and secretly due to Sparta's currency, the possession of which cannot simply be kept unnoticeable (VII, 5). Thirdly, never-endisng searches are conducted to reveal the items of value obtained through secret and dishonest enrichment, items of great value that can be easily hidden, e.g., gold and silver (VII, 6). These searches apparently indicate that there are such violators. ${ }^{36}$

As to the display of the skills of public submission in adulthood (that is, obedience and respect for the authorities), Xenophon provides two basic examples in peaceful and military life. The example of submission in military life is continuing a battle in a broken phalanx (XI, 6-7). Other Greeks can hardly understand why the Spartiates do not run when the troops are defeated, but the Spartiates never retreat without order. In the grip of strife, public submission, and the fear of leading the life of a coward, Spartan soldiers have no other choice but to continue to fight. That is why, compared to the Spartan combat formation and tactics, it "is not so easy to grasp, except for soldiers trained under the laws of Lycurgus" (XI, 7). As to peaceful life, the most powerful Spartiates "show the utmost deference to the magistrates: they pride themselves on their humility, on running instead of walking to answer any call" (VIII, 2). However, the citizens in the other Greek states consider the ability to disobey the authorities as a display or proof of their power. It seems that there are three main reasons for this. Certainly, the first one is the punishment discussed in the same chapter. The ephors rule "like tyrants" and immediately punish anyone who was noticed engaging in illegal conduct (VIII, 4). The second one is to set a pattern of ardent obedience to the authorities for other citizens (VIII, 2). The third one, apparently, is personal interest. The powerful Spartiates have a vested interest in Spartan discipline and, thus, maintain it in every possible way (cf. Proietty, 1987: 57). Xenophon hints at this several times. First, he states that Lycurgus did not establish the laws until

36. Strauss (1939: 515) was the first to introduce the idea that the chapter discloses the concealed practice of the illicit wealth accumulation that had become customary since his time (Hodkinson, 2005: 247-248; Humble, 2018a: 562-563). The family life, the last vestige of privacy, addresses the issue of spending the acquired wealth. Illicit gold and silver might be spent on precious gifts for the wives of the Spartiates (Humble, 2018a: 562). 
he aligned himself with the most powerful people in the state (1968: VIII, 1). Second, it was these people who accompanied him on his trip to Delphi and obtained the divine approval of the laws (VIII, 5). Third, they also contributed to the establishment of the highest authority in the state, i.e., the ephors (VIII, 3) ${ }^{37}$

There can be no doubt that it is the rich, i.e., the accomplished criminals ${ }^{38}$ imitating the essential Spartan traits of character who wield power in the state. Formulated differently, almost all of the Spartan elite are evidently corrupted. The elite are involved in such a brutal regime as the Spartan state only if this regime serves their interest, partially or directly (Hodkinson, 2005: 248). The Spartiates, suspended in an environment of mass surveillance, never-ending searches, immediate punishment, and continuous strife, are easily divided into those who have digested the lessons of the laws of Lycurgus and those who have failed to do so; stated differently, those who violate the laws, make money through secret and dishonest enrichment and have affairs, ${ }^{39}$ and those failed criminals who obey the laws of Lycurgus through punishment and public orderliness (cf. Christensen, 2016: 393).

Xenophon alludes to the solution of this puzzle by being outspokenly critical of contemporary Sparta in Chapter XIV. According to him, the Spartan regime declined not because the Spartiates started to violate the laws of Lycurgus, as they had always violated them (Humble, 1997: 239; Tuplin, 1994: 139; Humble, 2018a: 560-561). The fall of the Spartan hegemony is caused by the refusal of powerful people to imitate the traits required by the laws, to commit crimes secretly (Xenophon, 1968: XIV, 3), and to imitate manliness and dignity while they live in other Greek poleis as harmosts, i.e., when they are escaping the attention of Spartan society (XIV, 2 and $4-6) .{ }^{40}$ It seems that at least partially "the utmost limit of wisdom" $(\mathrm{I}, 2)$ of Lycurgus was the understanding that the strongest people in any state tend to violate the law, rather than maintain it, and that they are able to commit crimes and always aim for their empowerment and superiority over others (I, 9). ${ }^{41}$ Therefore, the state that fights this type of criminals debilitates, rather than toughens, itself. Hence, the state should not punish the strongest but, rather, co-opt them to support the regime (Humble, 1997: 68). This explains why Lycurgus established the laws and involved the most powerful people in the establishment for their profit (Hodkinson, 2005: 247-248; Proietti, 1987: 48, 57). Turning the best criminals into support for

37. According to Gerald Proietti, it is the strongest men and not Lycurgus who established some of the marriage laws to ensure their property (1987: 48).

38. The Anabiasis illustrates that successful thieves get good posts (Xenophon, 1998: IV, 6, 14-15).

39. Lycurgus apparently did everything in his power to legalize and normalize adultery (Xenophon, 1968: I, 5 and 7-9) (cf. Strauss, 1939: 505-507). Yet, it is almost impossible to do so without utterly destroying the institution of marriage and property inheritance.

40. Almost all modern researchers of the Lacedaimonion Politeia agree that it was not the corruption of the elite but, rather, their gradual refusal to imitate orderliness that ruined Sparta (Hodkinson, 2005: 268; Rahe, 2016: 29-30).

41. For example, Lysander and Ageselaus are described in this way in the Hellenica (Xenophon, 1961: II, 4, 29 and III, 4, 8). Vincent Azoulay dedicates a chapter of his monograph to envy caused by the promotion of the strife, emphasizing the strife among the elite (2018). Other scholars prove that the strife between adult Spartiates resulted in envy and mutual hatred (Humble, 1997: 209; Ducat, 2006: 19). 
the regime, Lycurgus established the laws that directly serve the reproduction of this alliance. The never-ending surveillance, limited privacy, immediate punishment, strife, etc. cultivated accomplished criminals, on the one hand, and a law-abiding majority on the other. Thus, the lawgiver managed to establish the most lasting and stable political order (Xenophon, 1968: XV, 1). Sparta was invincible as long as the corrupt elite imitated the complete orderliness, demonstrated respect for the authorities, and displayed manliness and obedience both at home and abroad. However, the elite's refusal to set the example in the polis and revealing of its true face outside it was a signal to ordinary Spartiates as well as the Greeks in general. To the former, it meant that the laws of Lycurgus were no longer followed. To the latter it signaled the drastic changes in the attitude toward Sparta; previously, the Greeks had praised the Spartan traditions but refused to copy them $(\mathrm{X}, 8)$, while, now, they were trying to unite so that they would not fall under the sway of Sparta $(\mathrm{XIV}, 6)$.

Though Xenophon is one of the creators of "the Spartan mirage", this is caused only by a superficial reading of his works in general and the Lacedaimonion Politeia in particular. Xenophon was neither fascinated nor disappointed by the Spartan state; he was dismayed by neither the Spartan military defeats nor the underwhelming behavior of some citizens of the polis; he was neither deceived nor bought; nor was he influenced by King Agesilaus and his inner circle. As befits a political philosopher, he carefully examined the state that claimed to be close to the best one. At the same time, in the treatise, Xenophon does not provide a meaningless description of the state institutions, their structure and functions, their ways of formation, and their history. Instead, he sets his mind on the central issue, namely, the civil education or upbringing of a virtuous or good citizen.

The Lacedaimonion Politeia is both the granting and refutation of the greatest achievement of the Spartan lawgiver. Lycurgus' success lies in his understanding of the limits of the political. He did not try to create a state that would do its best to implant various virtues in everyone or even most of its citizens, as he understood that this is impossible. $\mathrm{He}$ created the state that compelled all citizens to imitate only one virtue, manliness, which is, in his view, essential for the state's prosperity. Lycurgus was successful because he lowered the standards of a good state by putting the possible and not desirable at the top of the list; thus, he managed to create the most stable regime $(\mathrm{XV}, 1)$. Yet, the core of Spartan greatness is the core of Spartan decline. The success of Lycurgus is, in fact, his failure. Even the most stable regime is doomed to decay. However, a regime cannot simply justify its existence if it does not cultivate virtuous people and promote human excellence. The Spartan legislation rings hollow, even though it successfully achieved its goals. That is to say, it must be complemented. But, in what way?

Xenophon did not leave behind a single work dedicated to the issue of the best regime. However, this does not mean that Xenophon did not pose relevant questions or attempt to find answers to them. The Lacedaimonion Politeia shows that the opposite is true. However, to prove this suggestion and to find Xenophon's possible answer, one should address his entire heritage by going beyond this one treatise. The adoption of such a cohesive approach to the study of his philosophy may be productive, enabling not only 
the discovery of the outlines of the third possible classical model of the best regime (following the ones described by Plato and Aristotle) but also the indication of the alternative solution to the problem of the political - thus enabling a look not beyond only "the Spartan mirage", but also "Xenophon's mirage".

\section{References}

Aristotle (1932) Politics, Harvard: Harvard University Press.

Azoulay V. (2018) Xenophon and the Graces of Power: A Greek Guide to Political Manipulation, Swansea: The Classical Press of Wales.

Cartledge P. (1999) The Socratics' Sparta and Rousseau's. Sparta: New Perspectives (eds. S. Hodkinson, A. Powell), Swansea: The Classical Press of Wales, pp. 311-338.

Chrimes K. M. T. (1948) The Respublica Lacedaemoniorum Ascribed to Xenophon, Manchester: Manchester University Press.

Christensen P. (2016) Xenophon's Views on Sparta. The Cambridge Companion to Xenophon (ed. M. A. Flower), Cambridge: Cambridge University Press, pp. 376-399.

Dillery J. (2017) Xenophon: The Small Works. The Cambridge Companion to Xenophon (ed. M. A. Flower), Cambridge: Cambridge University Press, pp. 195-219.

Ducat J. (2006) Spartan Education. Youth and Society in the Classical Period, Swansea: The Classical Press of Wales.

Gray V. J. (2007) Xenophon on Government, Cambridge: Cambridge University Press.

Hansen M., Hodkinson S. (2009) Spartan Exceptionalism? Continuing the Debate. Sparta: Comparative Approaches (ed. S. Hodkinson), Swansea: The Classical Press of Wales, pp. 473-498.

Hodkinson S. (1994) "Blind Ploutos"? Contemporary Images of the Role of Wealth in Classical Sparta. The Shadow of Sparta (eds. A. Powell,S. Hodkinson), London: Routledge, pp. 183-222.

Hodkinson S. (2018) Sparta: An Exceptional Domination of State over Society? A Companion to Sparta, Vol. 1 (ed. A. Powell), Hoboken: John Wiley \& Sons, pp. 29-57.

Hodkinson S. (2005) The Imaginary Spartan Politeia. The Imaginary Polis (ed. M. Hansen), Copenhagen: The Royal Danish Academy of Sciences and Letters, pp. 222-281.

Hodkinson S. (2006) Was Classical Sparta a Military Society? Sparta and War (eds. S. Hodkinson, A. Powell), Swansea: The Classical Press of Wales, pp. 111-162.

Humble N. (2018a) Sparta in Xenophon and Plato. Plato and Xenophon: Comparative Studies (eds. G. Danzig, D. Johnson, D. Morrison), Boston: Brill, pp. 547-575.

Humble N. (2004) The Author, Date and Purpose of Chapter 14 of the "Lakedaimoniōn Politeia". Xenophon and His World (ed. C. Tuplin), Stuttgart: Franz Steinar Verlag, pp. 215-228.

Humble N. (2012) The Renaissance Reception of Xenophon's Spartan Constitution: Preliminary Observations. Xenophon: Ethical Principles and Historical Enquiry (eds. F. Hobden, C. Tuplin), Boston: Brill, pp. 63-88. 
Humble N. (2018b) Xenophon and Isocrates on Sparta. Trends in Classics, no 10, pp. 5674.

Humble N. (1997) Xenophon's View of Sparta: A Study of the "Anabasis", "Hellenica" and "Respublica Lacedaemoniorum" (PhD Thesis), Hamilton: McMaster University.

Lane M. (2016) Xenophon (and Thucydides) on Sparta (and Athens): Debating Willing Obedience Not Only to Laws, but Also to Magistrates. Philosophy for the City: Acts of the Fifth Congress of the Society for Ancient Philosophy 2016 (ed. C. Riedweg), Berlin: De Gruyter, pp. 121-132.

Lipka M. (2002) Xenophon's “Spartan Constitution”, New York: Walter de Gruyter.

Lockwood T. (2017) Judging Constitutions: Aristotle's Critique of Plato's Republic and Sparta. Archiv für Geschichte der Philosophie, no 4, pp. 353-379.

Lutz M. (1997) Civic Virtue and Socratic Virtue. Polity, vol. 29, no 4, pp. 565-592.

Machiavelli N. (2007) Discourses on the First Decade of Titus Livius, Mineola: Dover Publications.

Machiavelli N. (2008) The Prince, Cambridge: Hackett Publishing.

Mason H. (2018) The Literary Reception of Sparta in France. A Companion to Sparta, Vol. 2 (ed. A. Powell), Hoboken: John Wiley \& Sons, pp. 665-684.

Mehta V. (2016) Sparta, Modernity, Enlightenment. On Civic Republicanism: Ancient Lessons for Global Politics (ed. G. Kellow), Toronto: University of Toronto Press, pp. 205225.

Morris I. (2004) The Paradigm of Democracy: Sparta in Enlightenment Thought. Spartan Society (ed. T. Figueira), Swansea: Classical Press of Wales, pp. 339-362.

Oprea A. (2019) Pluralism and the General Will: The Roman and Spartan Models in Rousseau's “Social Contract”. The Review of Politics, no 81, pp. 573-596.

Plato (1926) Laws, Books I-VI, Harvard: Harvard University Press.

Plato (1942) Republic, Books I-V, Harvard: Harvard University Press.

Plato (1925) Symposium, Harvard: Harvard University Press.

Powell A. (2018) Sparta: Reconstructing History from Secrecy, Lies and Myth. A Companion to Sparta, Vol. 1 (ed. A. Powell), Hoboken: John Wiley \& Sons, pp. 3-28.

Powell A. (2015) Spartan Education. A Companion to Ancient Education (ed. M. Bloomer), Chichester: John Wiley \& Sons, pp. 90-111.

Proietti G. (1987) Xenophon's Sparta: An Introduction, Leiden: Brill.

Rahe P. A. (2016) The Spartan Regime: Its Character, Origins, and Grand Strategy, London: Yale University Press.

Rebenich S. (2018) Reception of Sparta in Germany and German-Speaking Europe. A Companion to Sparta, Vol. 2 (ed. A. Powell), Hoboken: John Wiley \& Sons, pp. 685703.

Roche H. (2012a) “Go, Tell the Prussians...”: The Spartan Paradigm in Prussian Military Thought During the Long Nineteenth Century. New Voices in Classical Reception Studies, no 7, pp. 25-39. 
Roche H. (2012b) "Spartanische Pimpfe": The Importance of Sparta in the Educational Ideology of the Adolf Hitler Schools. Sparta in Modern Thought. Politics, History and Culture (ed. S. Hodkinson), Swansea: Classical Press of Wales, pp. 315-342.

Shklar J. (1966) Rousseau's Two Models: Sparta and the Age of Gold. Political Science Quarterly, vol. 81, no 1, pp. 25-51.

Strauss L. (1939) The Spirit of Sparta or the Taste of Xenophon. Social Research, vol. 6, no 1 , pp. 502-536.

Strauss L. (1975) Xenophon's Anabasis. Interpretation: A Journal of Political Philosophy, vol. 4, no 3, pp. 117-147.

Talbert R. (2005) Plutarch on Sparta, London: Penguin Books.

Tigerstedt E. N. (1965) The Legend of Sparta in Classical Antiquity, Vol. 1. Lund: Hakan Ohlssons Bokrtryckeri.

Tuplin C. (1994) Xenophon, Sparta and the "Cyropaedia". The Shadow of Sparta (eds. A. Powell, S. Hodkinson), London: Routledge, pp. 127-181.

Xenophon (1998) Anabasis, Harvard: Harvard University Press.

Xenophon (1968) Constitution of the Lacedaemonians, Harvard: Harvard University Press.

Xenophon (1914) Cyropaedia, Books 5-8, Harvard: Harvard University Press.

Xenophon (1961) Hellenica, Books 1-5, Harvard: Harvard University Press.

Xenophon (2013a) Memorabilia, Harvard: Harvard University Press.

Xenophon (2013b) Symposium, Harvard: Harvard University Press.

\title{
Сила коррупции: Ксенофонт о воспитании хорошего гражданина в Спарте
}

\author{
Александр Мишурин \\ Кандидат политических наук, доцент, факультет политологии, Государственный академический \\ университет гуманитарных наук \\ Адрес: Мароновский переулок, д. 26, г. Москва, Российская Федерация 119049 \\ E-mail: amishurin@gaugn.ru
}

В статье автор пытается предложить интерпретацию труда античного политического философа Ксенофонта Афинского, озаглавленного «Лакедемонская полития». Отталкиваясь от редко отстаиваемого ныне представления о трезвости и непредвзятости Ксенофонта к изучаемому им строю, автор концентрируется на центральной проблеме трактата воспитании добродетельного или хорошего гражданина, ставшего залогом успеха Спарты как полиса и одновременно породившего ее славу как уникального политического образования, превозносимого всеми, но никем не копируемого. Автор последовательно прослеживает три ступени спартанского образования, описанные Ксенофонтом, а затем переходит к практикам его имплементации в зрелом возрасте. В ходе изысканий становится ясно, что законы Ликурга, как их описывает Ксенофонт, на самом деле служат двойной цели. С одной стороны, они прививают гражданам желаемые законодателем качества уважения 
и послушания, а также добродетель мужества; с другой — воспитывают людей, которые только имитируют их, равно как и свою законопослушность, а на деле скорее являются отъявленными преступниками, находящимися в постоянной борьбе друг с другом. Именно люди последнего типа - хорошие преступники - оказываются в Спарте у власти, и именно они, в конце концов, губят спартанское государство. Ставя такой диагноз спартанскому строю и законам Ликурга, Ксенофонт пытается показать, что решение проблемы создания хорошего гражданина, предложенное в Спарте, на самом деле является ошибочным и требует дополнительного осмысления.

Ключевые слова: Ксенофонт, Спарта, добродетель, имитация, воспитание, обучение 